\title{
Definition of a quantitative measurement method for acetabular version in a plain radiograph in the healthy adult hip
}

\author{
Sağlıklı erişkin kalçasında direkt radyografide asetabular versiyonun kantitatif \\ ölçüm yönteminin tanımlanması
}

\author{
Abdurrahman Özçelik, MD., ${ }^{1}$ Yavuz Akalın, MD., ${ }^{2}$ Cüneyt Çalışır, MD., ${ }^{3}$ \\ Ulukan İnan, MD., ${ }^{1}$ Hakan Ömeroğlu, MD. ${ }^{1}$ \\ 'Department of Orthopedics and Traumatology, Medical Faculty of Eskişehir Osmangazi University, Eskişehir, Turkey \\ 2Department of Orthopedics and Traumatology, Şevket Yılmaz Training and Research Hospital, Bursa, Turkey \\ ${ }^{3}$ Department of Radiology, Medical Faculty of Eskişehir Osmangazi University, Eskişehir, Turkey
}

\begin{abstract}
Objectives: This study aims to define a quantitative measurement method for acetabular version in a standard anteroposterior hip radiograph, assess the intraobserver and interobserver agreements of this method, and compare it with the gold standard computed tomography (CT).

Patients and methods: Anteroposterior standard hip radiographs and simultaneously taken transverse acetabular CT sections of 78 hips of 39 patients (10 males, 29 females; mean age 60 years; range 40 to 81 years) were used in the study. In standard anteroposterior hip radiographs, "acetabular anterior wall line" was identified as the line between the most lateral edge of the acetabulum and the inferolateral edge of the teardrop. "Acetabular posterior wall line" was identified as the line between the most lateral edge of the subchondral sclerosis and the outmost point of acetabulum posterior lunate surface sclerosis. To assess the reliability of this technique, mentioned angles in 78 hips were measured by two authors independently two weeks apart. Direct radiographic values were compared with the acetabular version measurement values in CT examination.
\end{abstract}

Results: Mean acetabular version angles of 78 hips in plain radiographs and $\mathrm{CT}$ were $18.0^{\circ}\left(9-25^{\circ}\right)$ and $17.2^{\circ}\left(12-25^{\circ}\right)$, respectively. Mean intraobserver measurement differences were $1.3^{\circ}\left(0-5^{\circ}\right)$ and $1.5^{\circ}\left(0-6^{\circ}\right)$. Mean interobserver measurement difference was $1.4^{\circ}\left(0-5^{\circ}\right)$. The mean difference between plain radiography measurements and $\mathrm{CT}$ measurements was $2.5^{\circ}$ $\left(0-6^{\circ}\right)$. A significant correlation was detected between plain radiographic measurements and $\mathrm{CT}$ measurements.

Conclusion: By this quantitative method, acetabular morphology may be measured less invasively, easily, quickly and reliably in plain radiograph in transverse plane.

Keywords: Acetabular version; computed tomography; measurement; plain radiography.
ÖZ

Amaç: $\mathrm{Bu}$ çalışmada asetabüler versiyon için standart ön-arka kalça grafisinde kantitatif bir ölçüm yönteminin tanımlanması, bu yöntemin gözlemciler içi ve gözlemciler arası uyumunun değerlendirilmesi ve altın standart olan bilgisayarlı tomografi (BT) ile karşılaştırılması amaçlandı.

Hastalar ve yöntemler: Otuz dokuz hastanın (10 erkek, 29 kadın; ort. yaş 60 yıl; dağılım 40-81 yıl) 78 kalçasının ön-arka standart kalça grafileri ve eş zamanlı çekilen transvers asetabüler BT kesitleri çalışmada kullanıldı. Standart ön-arka kalça grafilerinde "asetabulum ön duvar çizgisi" asetabulum en dış kenarı ile gözyaşı damlasının inferolateral kenarı arasında çizilen çizgi olarak belirlendi. "Asetabulum arka duvar çizgisi" ise subkondral sklerozun en dış kenarı ile asetabulum posterior lunat yüzey sklerozunun en diş noktası arasındaki çizgi olarak belirlendi. Tekniğin güvenirliğini değerlendirmek için 78 kalçada belirtilen açılar iki yazar tarafından bağımsız olarak iki hafta ara ile ölçüldü. Direkt radyografik değerler BT incelemesinde asetabüler versiyon ölçüm değerleri ile karşılaştırıldı.

Bulgular: Yetmiş sekiz kalçanın direkt grafilerdeki ve BT'deki ortalama asetabüler versiyon açıları sırasıyla $18.0^{\circ}$ $\left(9-25^{\circ}\right)$ ve $17.2^{\circ}\left(12-25^{\circ}\right)$ idi. Gözlemciler içi ortalama ölçüm farklılıkları sırasıyla $1.3^{\circ}\left(0-5^{\circ}\right)$ ve $1.5^{\circ}\left(0-6^{\circ}\right)$ idi. Gözlemciler arası ortalama ölçüm farklılı̆̆ $1.4^{\circ}\left(0-5^{\circ}\right)$ idi. Direkt radyografik ölçümler ile BT ölçümleri arasındaki ortalama farklılık $2.5^{\circ}\left(0-6^{\circ}\right)$ idi. Direkt radyografik ölçümler ile BT ölçümleri arasında anlamlı bir ilişki saptandı.

Sonuç: Bu kantitatif yöntemle direkt radyografide asetabüler morfoloji transvers planda daha az invaziv, kolay, hızlı ve güvenilir şekilde ölçülebilir.

Anahtar sözcükler: Asetabular version; bilgisayarlı tomografi; ölçüm; direk grafi.

- Received: December 03, 2014 Accepted: January 28, 2015

- Correspondence: Abdurrahman Özçelik, MD. Eskișehir Osmangazi Üniversitesi Tıp Fakültesi Ortopedi ve Travmatoloji Anabilim Dalı, 26040 Meşelik Eskişehir, Turkey. Tel: +90222 - 2392979 Fax: +90222 - 2391678 e-mail: abozcelik@ogu.edu.tr 
Acetabular version is defined as the forward inclination of the angle between the acetabular axis and the transverse axis in the transverse plane. Backward inclination of this angle is called retroversion. Measurement of acetabular version via computed tomography (CT) has been accepted as the gold standard method for many years. Several indicators such as cross-over sign, ${ }^{[1]}$ posterior wall $\operatorname{sign}^{[1]}$ or ischial spine $\operatorname{sign}^{[2]}$ have been defined for the identification of acetabular version in a standard plain radiograph and have been in use for many years. However, all these methods are based on qualitative definitions and a quantitative measurement of acetabular version in a standard anteroposterior pelvic radiograph seems to be needed. In this study, we aimed to define a quantitative measurement method for acetabular version in a standard anteroposterior hip radiograph, assess the intraobserver and interobserver agreements of this method, and compare it with the gold standard CT.

\section{PATIENTS AND METHODS}

The methodology and content of the study were initially approved by the institutional ethics committee. In this study, anteroposterior standard pelvis radiographs and concomitant transverse acetabular CT sections of 39 patients (10 males, 29 females; mean age 60 years; range 40 to 81 years) were examined in Department of Orthopedics and Traumatology, Medical Faculty of Eskişehir Osmangazi University between January 2004 and December 2004 Patients having osteoarthritisrelated changes such as narrowing of the joint space osteophytes in their plain radiographs or CT sections were not included. This data were also used for another study concerning the lower extremity rotation, which had been carried out at the same department. All plain radiographs were taken at a distance of $110 \mathrm{~cm}$. Iliac wings, teardrop, and obturator foramen were symmetric. Distance between symphysis pubis and sacrococcygeal joint was $25-40 \mathrm{~mm}$ in females and $40-55 \mathrm{~mm}$ in males in the middle line to prevent the effect of pelvic tilt. ${ }^{[3]}$

In a standard anteroposterior pelvic radiograph, "anterior acetabular wall line" was defined as the line drawn between the most lateral edge of the acetabulum superiorly and the inferolateral edge of the teardrop inferiorly. "Posterior acetabular wall line", on the other hand, was defined as the line drawn between the most lateral edge of the subchondral sclerosis superiorly and the outmost point of acetabulum posterior lunate surface sclerosis inferiorly. These points were marked on six cadaver pelvises and were verified radiographically as well.
The acetabulum version angle was the angle between the anterior and posterior acetabular wall lines in a plain radiograph (Figure 1). The measured angle had a negative value if anterior wall line was completely lateral to the posterior acetabular wall line.

For the assessment of the intraobserver and interobserver measurement reliabilities of this technique, the angle was measured twice two weeks apart by two of the authors independently. In each hip, the mean value of four measurements from two authors was considered as the final acetabulum version angle in a plain radiograph.

Computed tomography sections of the patients were taken at supine position in the removable plexiglass support, which keeps extremities and the pelvis in horizontal and parallel position by covering them to prevent the movement of lower extremities and the pelvis. ${ }^{[4]}$ Measurements in CT sections were taken at sections where femur neck and head were fully shaped and the congruency between the acetabulum and femoral head was complete. In the sections, the line connecting the posterior edges of both acetabular fossae was defined as the baseline. The acetabular version angle was measured between the sagittal plane line drawn vertically to the baseline and the line connecting the anterior and posterior edges of the acetabulum (Figure 2). ${ }^{[5]}$

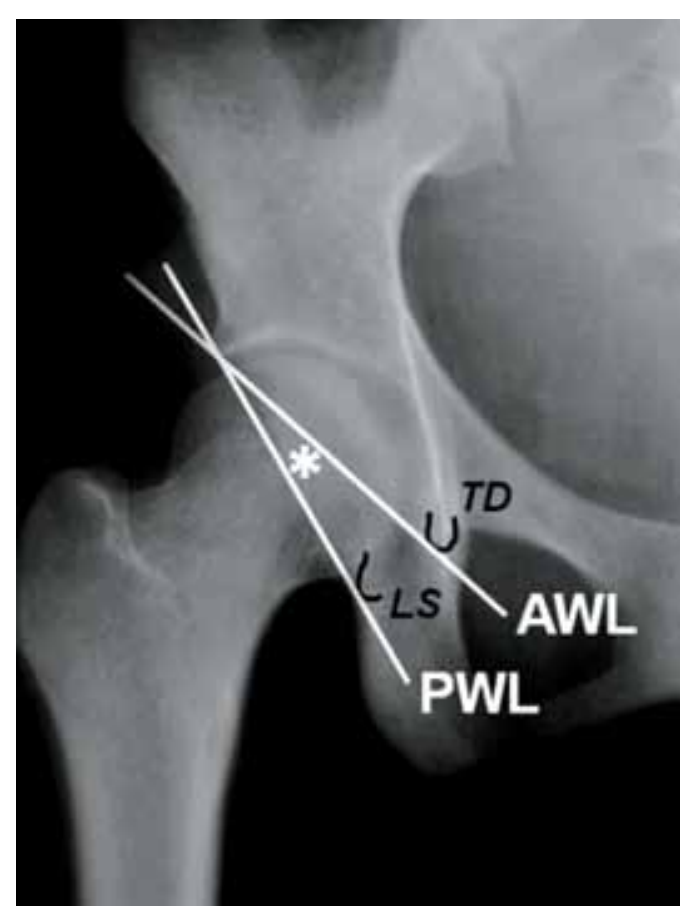

Figure 1. Measurement of acetabular version in a plain anteroposterior radiograph. AWL: Anterior wal line; PWL: Posterior wall line; TD: Tear drop; LS: Lunate sclerosis; *: Acetabular version angle. 


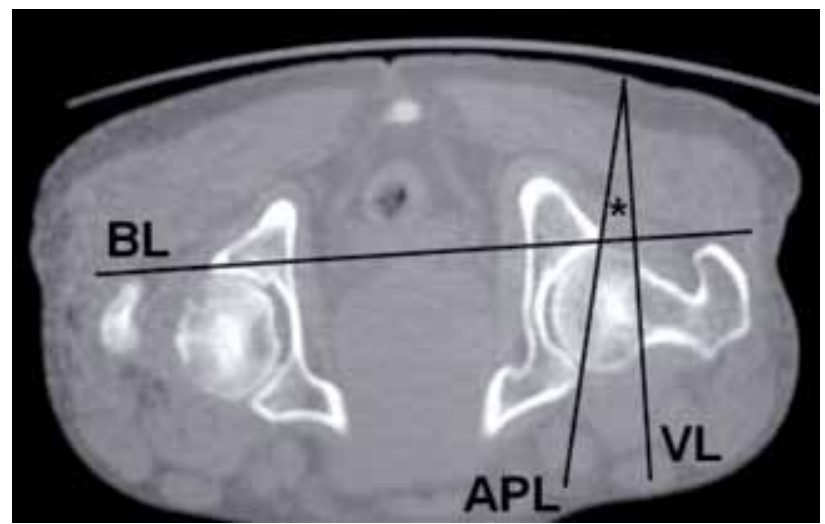

Figure 2. Measurement of acetabular version in a computed tomography section. BL: Baseline; VL: Vertical line to base line; APL: Line connecting anterior and posterior edges of acetabulum; *: Acetabular version angle.

If the anterior edge of the acetabulum was lateral to the posterior edge of the acetabulum in the transverse plane, then the angle was expressed as a negative value. These measurements were made by one of the authors blinded to the plain radiographic measurement values.

Pearson correlation test was used for the statistical analysis of the data and a $p$ value less than 0.05 was considered significant.

\section{RESULTS}

In the measurements obtained from plain radiographies and $\mathrm{CT}$ sections, none of the hips had negative values. Mean acetabular version angle of 78 hips in plain radiographs and in CT were $18.0^{\circ}\left(9-25^{\circ}\right)$ and $17.2^{\circ}\left(12-25^{\circ}\right)$, respectively. Mean intraobserver measurement variability of the radiographic measurements was $1.3^{\circ}\left(0-5^{\circ}\right)$ and $1.5^{\circ}$ $\left(0-6^{\circ}\right)$ for the two authors. The difference between the two separate measurements was within the range of $0-2^{\circ}$ in $85 \%$ of measurements of both authors. Mean interobserver measurement variability, on the other hand, was $1.4^{\circ}\left(0-5^{\circ}\right)$ and this difference was within the $0-2^{\circ}$ range in $85 \%$ of measurements.

The mean difference between plain radiographic measurements and CT measurements was $2.5^{\circ}\left(0-6^{\circ}\right)$ and this difference was between 0 and $4^{\circ}$ in $89 \%$ of the hips. A statistically significant correlation $(R=0.664$, $\mathrm{p}<0.001)$ was detected between plain radiographic measurements and CT measurements.

\section{DISCUSSION}

With the improvement in diagnostic modalities, it has been understood that the hip joint is more complex than it has been considered to be. For the exact definition and appropriate management planning of the hip disorders, it is necessary to examine the acetabulum, femur head and neck in detail and to correctly assess their relations. While making this definition as well as management planning, plain radiography, CT and magnetic resonance imaging are the most commonly used methods in addition to the clinical examination. Hip osteoarthritis due to deviations from the normal acetabular version is an important health issue, ${ }^{[6,7]}$ and this has led researchers to focus on determining this version problem as well as on the measurement methods concerning acetabular rotation in the transverse plane.

It has been stated that the high radiation effect of CT, which is considered as the gold standard among these methods, should be avoided and that conventional radiography can be sufficient for primary diagnosis. ${ }^{[5]}$ In a hip with normal anatomy, the acetabular fossa is anteverted. The number of articles concerning hip retroversion is significantly increasing since the cross-over sign in a plain radiograph has initially been defined by Reynolds et $a{ }^{[1]}$ and the concept of decreased anteversion in a plain radiograph has been discussed by Tönnis ve Heinecke ${ }^{[3]}$ Acetabular retroversion has been considered as one of the main etiological factors of pincer type femoroacetabular impingement that can lead to hip osteoarthritis within years. ${ }^{[8,9]}$

Knowing the exact acetabular version may indeed guide the physician in particularly determining the management strategy. Instead of using a qualitative definition such as anteversion or retroversion, measuring the acetabular version using a quantitative method may provide important advantages. Koyama et al. ${ }^{[10]}$ recently defined a new quantitative index for evaluating the acetabular version in a plain radiograph. However, the defined quantitative ratio assesses whether or not an acetabular retroversion exists, not the exact quantity of acetabular version. The defined simple method in this study provides an exact definition of the acetabular morphology in the transverse plane similar to the CT, whereas cross-over sign, posterior wall sign or ischial sign define whether or not a transverse plane deformity exists, but cannot make a quantitative description of the transverse plane deformity. As the defined method has almost similar measurement values with $\mathrm{CT}$, we think that such a simple method provides a significant advantage in the clinical practice in terms of lessening the radiation exposure and reducing the costs in the diagnosis. Besides, considerable repeatability has a significant impact on the use of this defined technique in the daily clinical practice. 
A limitation of this study is that it included the quantitative measurements in the healthy hips of adult subjects and did not evaluate the usability of this measurement technique in real retroverted or dysplastic hips in which the shape of the teardrop could be distorted. Thus, usability of the defined technique in pathologic hips needs to be validated. Besides, the measurements were made in adult subjects within a certain age interval and the usability of this technique in young adults and adolescents needs to be evaluated.

We conclude that acetabular version can be measured by exposing the patient to less radiation, more easily and faster than, but as reliably as CT measurements using the newly defined quantitative method. Still, efficacy of the presented technique needs to be examined in pathologic hips.

\section{Declaration of conflicting interests}

The authors declared no conflicts of interest with respect to the authorship and/or publication of this article.

\section{Funding}

The authors received no financial support for the research and/or authorship of this article.

\section{REFERENCES}

1. Reynolds D, Lucas J, Klaue K. Retroversion of the acetabulum. A cause of hip pain. J Bone Joint Surg [Br]
1999;81:281-8.

2. Kalberer F, Sierra RJ, Madan SS, Ganz R, Leunig M. Ischial spine projection into the pelvis: a new sign for acetabular retroversion. Clin Orthop Relat Res 2008;466:677-83.

3. Tönnis D, Heinecke A. Acetabular and femoral anteversion: relationship with osteoarthritis of the hip. J Bone Joint Surg [Am] 1999;81:1747-70.

4. Seber S, Hazer B, Köse N, Göktürk E, Günal I, Turgut A. Rotational profile of the lower extremity and foot progression angle: computerized tomographic examination of 50 male adults. Arch Orthop Trauma Surg 2000;120:255-8.

5. Visser JD, Jonkers A, Hillen B. Hip joint measurements with computerized tomography. J Pediatr Orthop 1982;2:143-6.

6. Sarıkaya B, Ataoğlu B, Görmeli G, Öztürk BY, Turanlı S. Eight-year follow-up of uncemented hydroxyapatite coated hip prosthesis for hip osteoarthritis secondary to developmental hip dysplasia. [Article in Turkish] Eklem Hastalik Cerrahisi 2013;24:91-5.

7. Konya MN, Tuhanioğlu Ü, Aslan A, Yıldırım T, Bursalı A, Şahin V, et al. A comparison of short-term clinical and radiological results of Tönnis and Steel pelvic osteotomies in patients with acetabular dysplasia. [Article in Turkish] Eklem Hastalik Cerrahisi 2013;24:96-101.

8. Siebenrock KA, Schoeniger R, Ganz R. Anterior femoroacetabular impingement due to acetabular retroversion. Treatment with periacetabular osteotomy. J Bone Joint Surg [Am] 2003;85:278-86.

9. Ganz R, Parvizi J, Beck M, Leunig M, Nötzli H, Siebenrock KA. Femoroacetabular impingement: a cause for osteoarthritis of the hip. Clin Orthop Relat Res 2003;417:112-20.

10. Koyama H, Hoshino H, Suzuki D, Nishikino S, Matsuyama Y. New radiographic index for evaluating acetabular version. Clin Orthop Relat Res 2013;471:1632-8. 